\title{
Angiostrongylus costaricensis (Nematoda: Protostrongylidae): migration route in experimental infection of Omalonyx sp. (Gastropoda: Succineidae)
}

\author{
Lângia C. Montresor • Teofânia H. D. A. Vidigal • \\ Cristiane L. G. F. Mendonça • André A. Fernandes • \\ Karyne N. de Souza • Omar S. Carvalho • \\ Luzia F. G. Caputo • Ester M. Mota $\cdot$ Henrique L. Lenzi
}

Received: 24 June 2008 / Accepted: 17 July 2008 / Published online: 20 August 2008

(C) Springer-Verlag 2008

\begin{abstract}
Angiostrongylus costaricensis can infect several mollusks, and its migration route in intermediate hosts has been studied only in Sarasinula marginata. To verify the susceptibility of Omalonyx sp. as an intermediate host of $A$. costaricensis and to analyze the nematode migration route, individuals were infected with stage 1 larvae. Obtained stage 3 larvae were orally inoculated in mice, and after 30 days, adult worms and stage 1 larvae were recovered, demonstrating Omalonyx susceptibility and suitability to infection. To define the parasite migration routes, specimens of Omalonyx with 30 min, 1 h, 2 h, 4 h, 6 h, 8 h, 2 days, 5 days, 10 days, 12 days, 15 days, 20 days, 21 days, 25 days, 28 days, and 30 days of infection were fixed and
\end{abstract}

Fapemig, FIOCRUZ, and Pibic UFMG.

L. C. Montresor $(\bowtie) \cdot$ T. H. D. A. Vidigal $\cdot$ K. N. de Souza

Laboratório de Malacologia e Sistemática Molecular,

Departamento de Zoologia,

Universidade Federal de Minas Gerais,

Belo Horizonte, Minas Gerais, Brazil

e-mail: 1cmontresor@gmail.com

\section{A. A. Fernandes}

Departamento de Medicina Veterinária Preventiva,

Escola de Veterinária, Universidade Federal de Minas Gerais,

Belo Horizonte, Minas Gerais, Brazil

C. L. G. F. Mendonça • O. S. Carvalho

Laboratório de Helmintoses Intestinais,

Centro de Pesquisas René Rachou,

Fundação Oswaldo Cruz,

Belo Horizonte, Minas Gerais, Brazil

L. F. G. Caputo $・$ E. M. Mota $\cdot$ H. L. Lenzi

Departamento de Patologia, Instituto Oswaldo Cruz,

Fundação Oswaldo Cruz,

Rio de Janeiro, Rio de Janeiro, Brazil serially sectioned. Histological sections were stained with hematoxylin-eosin. The results were compared to those described in S. marginata. Oral and cutaneous infections were noted. After the penetration, larvae were retained, mainly in the fibromuscular tissue, by hemocytes, or they spread to the whole organism through the circulation, following the anatomical structure of the vasculature. The perilarval hemocyte reaction in Omalonyx was more intense until stage 2 larva instar, decreasing in the presence of stage 3 larvae. Differences in some aspects of hemocyte reaction between $S$. marginata and Omalonyx exemplify interspecific peculiarities in snail response to the same parasite.

\section{Introduction}

Studies on different aspects of the nematode Angiostrongylus costaricensis Morera and Céspedes 1971 infection in mollusk have been carried out by several investigators (Morera and Ash 1971; Conejo and Morera 1988; Thiengo 1996; Rambo et al. 1997; Bonetti and Graeff-Teixeira 1998; Mendonça et al. 1999, 2003; Banevicius et al. 2006). Mollusks from the Veronicellidae family are the main intermediate hosts in endemic areas in Costa Rica (Morera and Ash 1971), Ecuador (Morera et al. 1983), Honduras (Kaminsky et al. 1987), Nicaragua (Duarte et al. 1992), and Brazil (Graeff-Teixeira et al. 1989; Rambo et al. 1997; Bonetti and Graeff-Teixeira 1998; Laitano et al. 2001). However, several species belonging to other Pulmonata families were also found naturally infected (Graeff-Teixeira et al. 1993; Rambo et al. 1997), besides the families that were shown as potential hosts in experimental trials (Ubelaker et al. 1980; Lima et al. 1992). Although the 
parasite lifecycle may occur in several mollusks, its migration route was described only in Sarasinula marginata (Pulmonata: Soleolifera: Veronicellidae), due to the epidemiological importance of this family (Mendonça et al. 1999). Therefore, the host cellular reaction patterns, the migration routes, characteristics of larval maturation, and elimination sites in mollusks of other families are unknown.

Mollusks of the genus Omalonyx (Pulmonata: Stylommatophora: Succineidae) are terrestrial and live in vegetation emerging from freshwater flows (Barker 2001). They are present in several regions in the Caribbean and Central and South Americas (Patterson 1971; Tillier 1981). Malacological surveys on such mollusks are impaired due to their color pattern (camouflage), leading to an underestimated distribution. Even so, many specimens were collected in water flows, with different degrees of anthropic impact, as well as in vegetables from commercial stores. Economical and epidemiological implications of the presence of mollusks in vegetable-garden have been reported by Chiaradia et al. (2004). These places provide shelter, humidity, and food for mollusk survival and reproduction (South 1992), explaining the presence of several genera, including Omalonyx, in these special ecological sites.

Considering the coincident geographical distribution of A. costaricensis and mollusks of the genus Omalonyx in some regions of South America, the present investigation aimed at evaluating the susceptibility and suitability of Omalonyx as an intermediate host, the characteristics of its perilarval reactions, and the migration routes followed by the larvae during the maturation process from L1 to L3.

\section{Materials and methods}

Intermediate host

Specimens of Omalonyx sp., raised under laboratory conditions, from parental specimens were obtained from an ecological reserve (Reserva Particular do Patrimônio Nacional Feliciano Miguel Abdala) located in the county Caratinga,

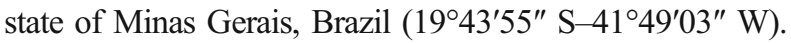

Parasites

A. costaricensis $\mathrm{L} 1$ were obtained from a cycle kept at the Pathology Department of Instituto Oswaldo Cruz (FIOCRUZ), through successive passages in slugs (S. marginata) and rodents (Sigmodon hispidus).

Mollusk infection

The feces of infected S. hispidus were collected and placed in a Baermann apparatus to separate the decanted L1
(Willcox and Coura 1989). After 2 days of fasting, mollusks were individually fed with a fragment of lettuce covered with healthy mice feces and a concentrate of 1,200 L1 (Morera 1973).

Mice infection

To verify whether L3 from Omalonyx sp. (20 days of infection) were infective, ten specimens were cleaved and digested for $2 \mathrm{~h}$ at $37^{\circ} \mathrm{C}$ according to Wallace and Rosen's (1969) procedure. The infectious larvae were inoculated in Swiss Webster mice by a gastric probe. Each mouse was infected with seven to ten L3. After 30 days of infection, ten animals were submitted to euthanasia by ether inhalation in accordance with the animal ethical practice. Adult worms were searched in mesenteric and portal-hepatic circulation.

Histological study of infected Omalonyx

The study was performed at $30 \mathrm{~min}, 1 \mathrm{~h}, 2 \mathrm{~h}, 4 \mathrm{~h}, 6 \mathrm{~h}$, and $8 \mathrm{~h}$ and on $2,5,10,12,15,20,21,25,28$, and 30 days (one specimen each). The whole snails were fixed in Carson' modified Millonig's phosphate-buffered formalin (Carson et al. 1973) and embedded in paraffin. Serial sections $(5 \mu \mathrm{m})$ were consecutively (one out of six slides) stained in hematoxylin and eosin. Sections were analyzed under bright-field microscopy (Olympus CH30), and images were captured with an analogical camera PMC35B, exposimeter PM-PBK3, and negative Kodak Pro Image 100 ASA.

The results obtained were compared with those described for S. marginata (Mendonça et al. 1999, 2003).

\section{Results}

Recovery of adult worms in mice

After 30 days of infection, mature male and female adult worms were recovered from mesenteric arteries (Fig. 1, 1). The maturity of the worms was confirmed by microscopic analysis and by L1 detection in the feces by Baermann procedure.

Histological study of infected Omalonyx

\section{Oral infection}

Larvae were found in the lumen of digestive tract (Fig. 1,2) at $30 \mathrm{~min}$ and $1,2,4,6$, and $8 \mathrm{~h}$ of infection. At $6 \mathrm{~h}$, a significant reduction in the number of larvae was detected, decreasing even more at $8 \mathrm{~h}$. After 2 days, larvae 
Fig. 11 , A couple of $A$. costaricensis adult worms (arrow) in the mesenteric plexus of Swiss Webster mice. Scale bar $=5.2 \mathrm{~mm} .2$, A. costaricensis L1 (arrow) in the intestinal lumen (asterisk) of Omalonyx sp. (30 min of infection). Hematoxylin-eosin. Scale bar $=$ $160 \mu \mathrm{m}$. 3, L1 (arrow) close to the intestinal mucosa surface of Omalonyx sp. A thin layer of mucous is interposed between the larva and the epithelial surface (30 min of infection). Hematoxylin-eosin. Scale bar= $40 \mu \mathrm{m}$. 4, Two L1 (arrow) crossing the intestinal epithelium of Omalonyx sp. Intestinal lumen: asterisk (30 min of infection). Hematoxylin-eosin. Scale bar $=40 \mu \mathrm{m} .5, \mathrm{L1}$ (arrow) in the subepithelial connective tissue of the intestine (asterisk) of Omalonyx sp. (30 min of infection). Hematoxylin-eosin. Scale bar $=40 \mu \mathrm{m}$. 6, Digestive gland (closed asterisk) ducts (open asterisk) communicating with the digestive tract lumen of Omalonyx sp. (30 min of infection). Hematoxylin-eosin. Scale bar $=400 \mu \mathrm{m}$. 7, Presence of larvae in one branch of digestive gland duct, which connects the digestive gland to the digestive tract lumen (arrow) of Omalonyx sp. (30 min of infection). Hematoxylin-eosin. Scale bar $=112 \mu \mathrm{m} .8, \mathrm{~L} 1$ (arrow) crossing the digestive gland tissue of Omalonyx sp. (30 min of infection). Hematoxylineosin. Scale bar $=32 \mu \mathrm{m}$
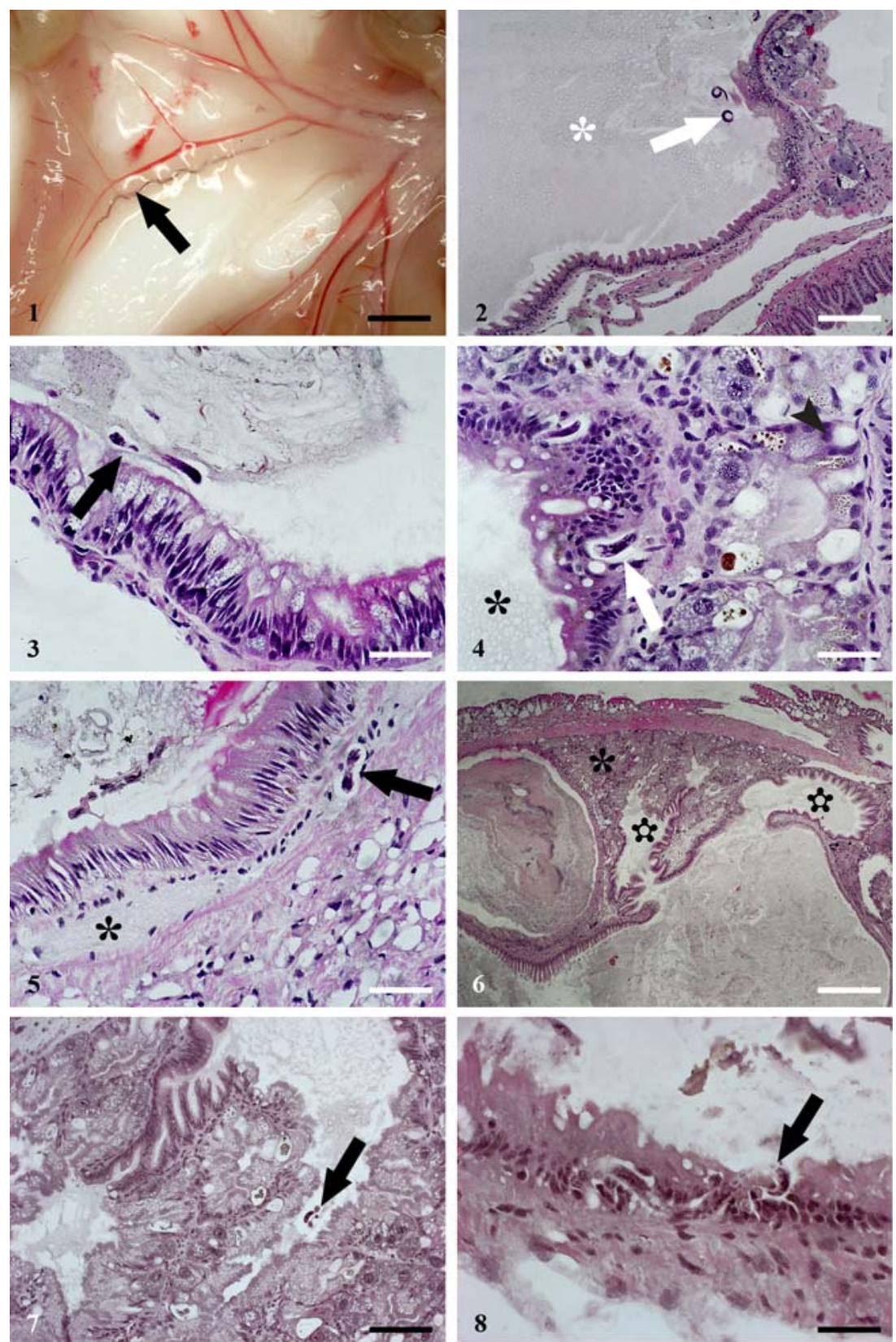

disappeared from the digestive tract lumen. After $30 \mathrm{~min}$ and 1,2 , and $4 \mathrm{~h}$, larvae were seen in contact with the superficial layer of mucosa epithelium (Fig. 1, 3), crossing the epithelium (Fig. 1, 4) and basal membrane, and reaching the subepithelial connective tissue (Fig. 1, 5). Larvae penetrated randomly in any segment of the digestive tract, with no preferential site. Some larvae migrated to the digestive gland through its duct (Fig. 1, 6, 7, and 8).

\section{Cutaneous infection}

Several larvae were found penetrating the tegument at 30 min of infection, causing dissociation of epithelial cells
(Fig. 2, 9). At $30 \mathrm{~min}$, a large number of larvae were found in the foot (Fig. 2, 10) and in the ventral region of the animal. From $30 \mathrm{~min}$ to 30 days of infection, larvae were mainly located in the fibromuscular tissue, into and next to the mucous glands, surrounded or not by pregranulomatous reaction (Fig. 2, 11, 12, 13, and 14). From $30 \mathrm{~min}$ up to $8 \mathrm{~h}$, free larvae were found in the sinuses and vessels of the circulatory system (Fig. 2, 15). Occasionally, some of these larvae were retained by cellular reaction in the circulatory system, until the most advanced times of infection (15 to 30 days; Figs. 2, 16 and 3, 17).

The distribution of the larvae during the development of $A$. costaricensis infection in Omalonyx sp. is shown in Table 1. 

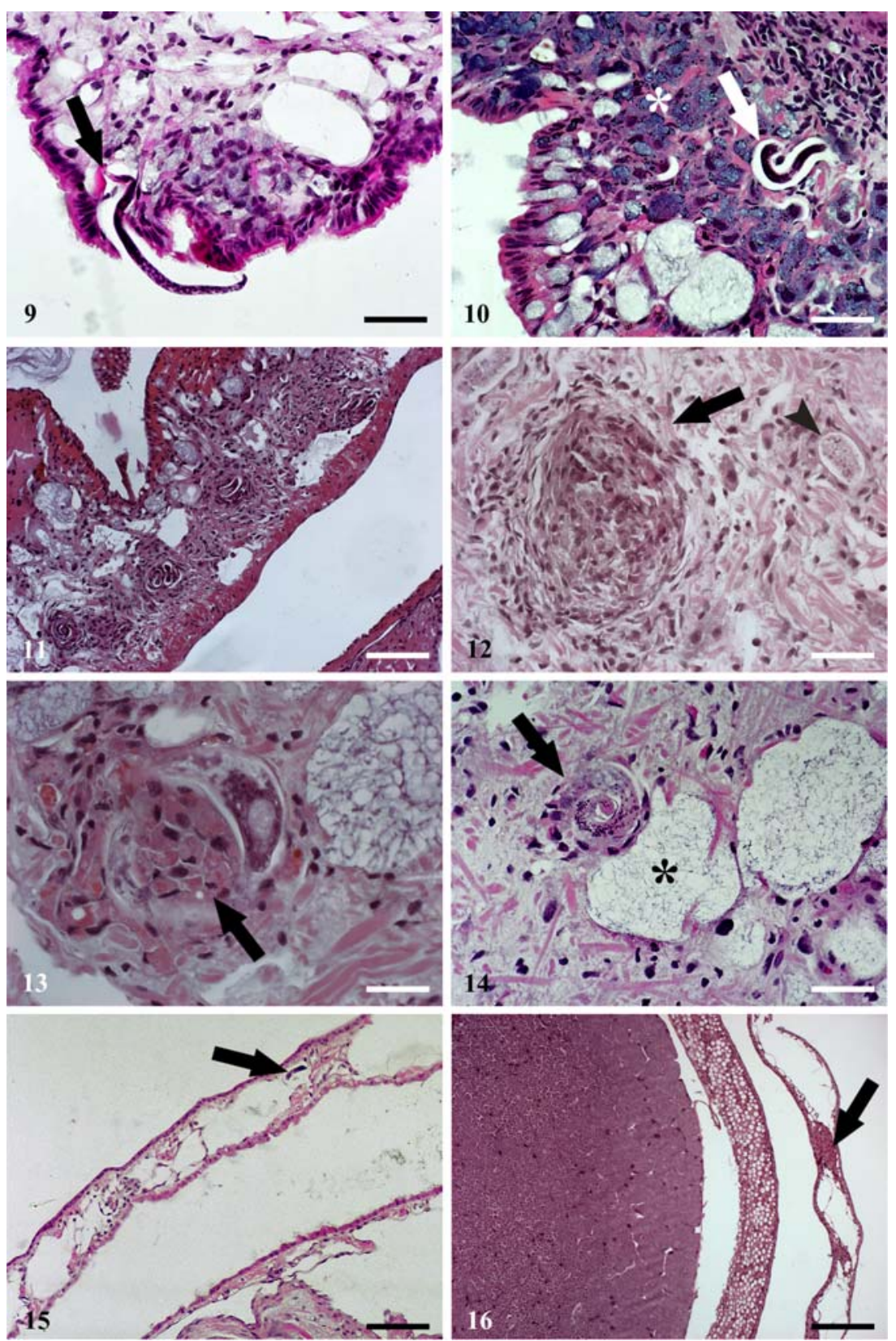

Fig. 2 9, L1 penetrating and dissociating epithelial cells of the tegument (arrow) of Omalonyx sp. (30 min of infection). Hematoxylin-eosin. Scale bar $=40 \mu \mathrm{m} .10, \mathrm{~L} 1$ (arrow) in the foot (asterisk) of Omalonyx sp., close to secretory glands. The larva is surrounded by empty space (protease secretion? $30 \mathrm{~min}$ of infection). Hematoxylin-eosin. Scale bar $=40 \mu \mathrm{m}$. 11, Several L1 in the fibromuscular layer of Omalonyx sp. surrounded by pregranulomatous hemocyte reaction ( 2 days of infection). Hematoxylin-eosin. Scale bar $=112 \mu \mathrm{m}$. 12, Typical hemocyte granuloma in the fibromuscular tissue of Omalonyx sp., presenting fibroblast-like cells (hemocytes) in the peripheral region (arrow), adjacent to a larva with a limited or scarce perilarval hemocyte reaction

\section{Perilarval reaction}

After $4 \mathrm{~h}$ of infection, an initial hemocyte response was observed close to some L1 (Fig. 3, 18). In the course of

(arrowhead; 20 days of infection). Hematoxylin-eosin. Scale bar $=50 \mu \mathrm{m} .13$, L3 in the fibromuscular tissue of Omalonyx sp. with hypertrophic hemocytes forming an aggregate in its concave surface (arrow; 30 days of infection). Hematoxylin-eosin. Scale bar $=32 \mu \mathrm{m}$. 14, Twisted L3 (arrow) close to a mucous gland in the fibromuscular layer (asterisk) of Omalonyx sp. (30 days of infection). Hematoxylineosin. Scale bar $=40 \mu \mathrm{m}$. 15, Larvae (arrow) in a lung hemolymphatic vessel (asterisk) of Omalonyx sp. (8 h of infection). Hematoxylin-eosin. Scale bar $=112 \mu \mathrm{m}$. 16, Granulomatous hemocyte reaction retaining larvae inside a hemolymphatic vessel (arrow) of Omalonyx sp. (15 days of infection). Hematoxylin-eosin. Scale bar $=225 \mu \mathrm{m}$

infection, coinciding with L2 development, hemocytes became more numerous and more organized mainly in the concave surface of the larvae (Fig. 3, 19 and 20). After L3 emergence, there was a significant reduction in the intensity 


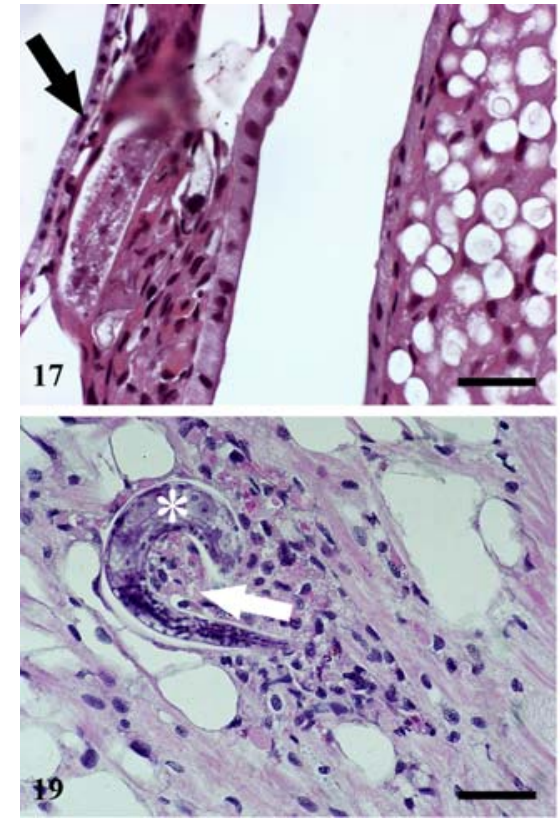

Fig. 317 , Detail of a larva retained by hemocyte reaction in a hemolymphatic vessel of the pulmonary cavity (arrow) of Omalonyx $\mathrm{sp}$. The vessel is surrounded by a cubical respiratory epithelium (15 days of infection). Hematoxylin-eosin. Scale bar=32 $\mu \mathrm{m}$. 18, Initial pregranulomatous hemocyte reaction surrounding L1 (arrow) in the fibromuscular tissue of Omalonyx sp. (4 h of infection). Hematoxylineosin. Scale bar $=40 \mu \mathrm{m} .19$, Hemocyte reaction to L2 (asterisk) located

of hemocyte response, sometimes presenting isolate parasites with no surrounding cells (Fig. 2, 14).

\section{Discussion}

This investigation showed that the pulmonate mollusk Omalonyx sp. (Stylommatophora: Succineidae) is susceptible and suitable to A. costaricensis oral and cutaneous infections and presents hemocyte reaction to the larvae that varies in intensity according to the larval stage.

The susceptibility of this mollusk to A. costaricensis infection was confirmed by L3 infection in Swiss Webster mice, resulting in adult worms recovered in mesenteric arteries and L1 release in the feces, indicating the Omalonyx potential as a natural host for A. costaricensis. Succineid snails, including the genus Omalonyx, are known to be intermediate hosts of trematodes of the family Leucochloridiidae (Lutz 1921; Casey et al. 2003).

The histological analysis showed concomitant occurrence of oral and cutaneous infections (Figs. 1, 2 and 2,9) as was also observed in S. marginata. After oral infection, L1 penetration in the digestive tract wall followed some clear steps: 1-adhesion to epithelium surface (Fig. 1: 3), 2-transepithelial migration until basal membrane (Fig. 1, 4), and 3-basal membrane transposition and invasion of connective subepithelial tissue (Fig. 1, 5). These steps were

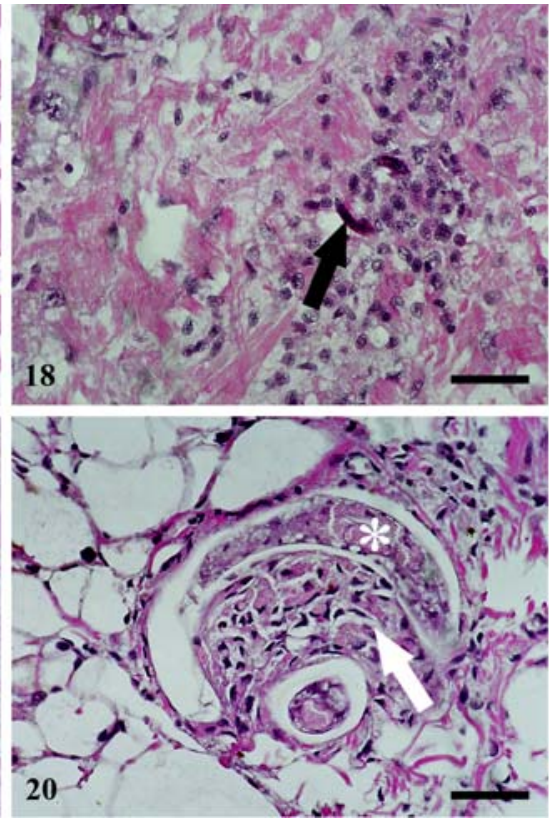

in the fibromuscular tissue of Omalonyx sp., showing cell migration to the concave surface of the larvae (arrow; 5 days of infection). Hematoxylin-eosin. Scale bar $=40 \mu \mathrm{m}$. 20, Pregranulomatous reaction (arrow) around transitional L2 (asterisk), with activated hemocytes most of them concentrated in the concave face of the larvae (arrow; 12 days of infection). Hematoxylin-eosin. Scale bar $=40 \mu \mathrm{m}$

firstly described in S. marginata (Mendonça et al. 1999), where, as in the present study, L1 penetrated the gastrointestinal wall without evidence of segmental preference. This penetration steps were also reported with L3 in the intestine of the definitive host by Mota and Lenzi (2005), showing that $A$. costaricensis uses similar strategies in very distinct hosts (vertebrates and invertebrates).

Cutaneous infection was clearly evidenced by the detection of $\mathrm{L} 1$ penetrating into the tegument after $30 \mathrm{~min}$ of infection (Fig. 2, 9) and by the presence of $\mathrm{L} 1$ in the superficial region of the fibromuscular tissue soon after $30 \mathrm{~min}$ of infection (Fig. 2, 10). In S. marginata, in addition to direct penetration in the tegument, L1 also penetrated through characteristic excretory ducts that drain the mucous of several secretory cells deeply located in the fibromuscular tissue (Mendonça et al. 1999). However, Omalonyx sp. tegument glands are unicellular, and larvae penetrate only through the surface epithelium (Fig. 2, 9).

Metastrongyloidea infection in mollusk intermediate hosts occurs through direct penetration in the tegument, by ingestion, or even by a combination of both mechanisms (Hobmaier and Hobmaier 1934; Cheng and Alicata 1965; Richards and Merritt 1967). The penetration process probably depends on proteases secretion, instead of the interaction between ligands in the larvae, and receptors in the epithelium from the tegument or from the digestive tract. This mechanism can explain the promiscuity of $A$. 


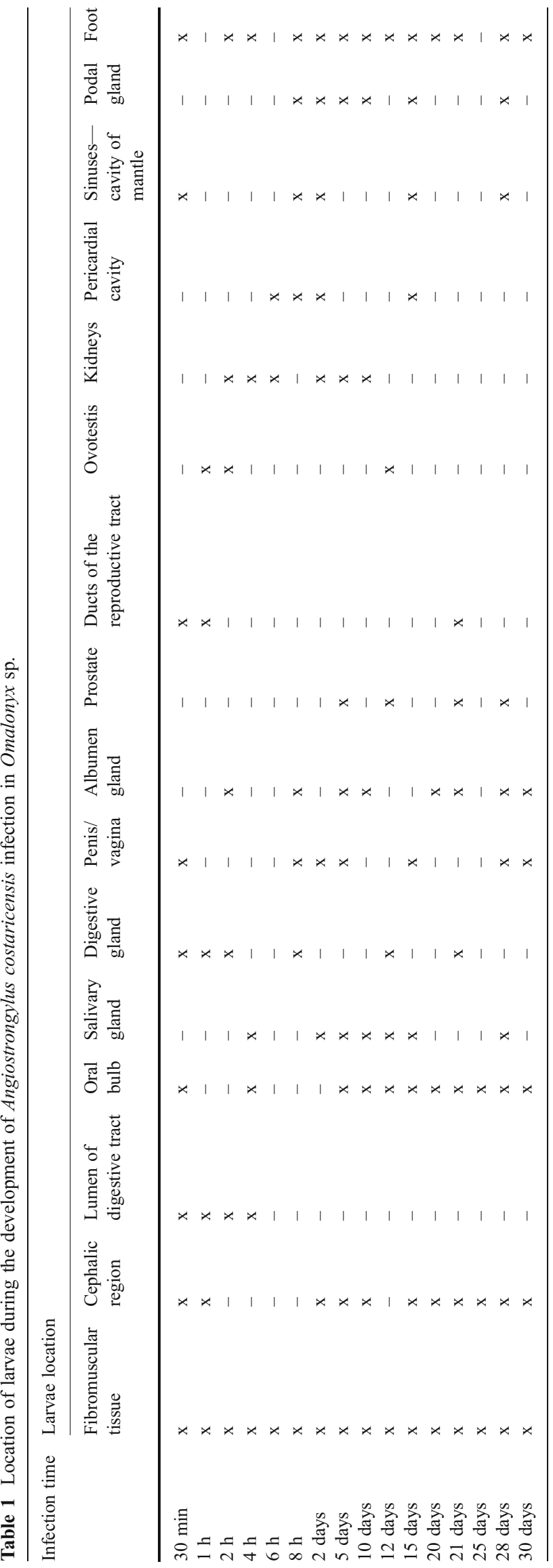

costaricensis in relation to the infection of invertebrate and vertebrate hosts. Proteases act as spreading factors or operate in extracorporeal digestion (Lee 1965).

Oral infection by $A$. costaricensis in mollusks was first described by Morera (1973). Thiengo (1996), using the $S$. marginatalA. costaricensis model, showed simultaneous occurrence of cutaneous and oral infections, through histological sections. Both ways were confirmed by Mendonça et al. (1999) in an experimental infection of $S$. marginata and now in this work with Omalonyx sp.

During the migration process, after the penetration step, larvae can be retained in some places, mainly in the fibromuscular tissue, by hemocyte reactions, or they spread all over the organism through the circulation, following the vascular and sinuses distributive anatomical patterns. Pulmonate circulatory system comprises the heart, within the pericardium, with one auricle (receiving blood from the pulmonary vein) and one ventricle (releasing blood through the aorta). The aorta is divided in two principal branches whose ramifications carry on blood to the viscera (posterior aorta) and head-foot region (anterior aorta). Due to the absence of a capillary system, blood in the viscera and the fibromuscular layer circulates in pseudovascular spaces of connective tissue (sinuses). In its return, blood (hemolymph) is retained in three great spaces, cephalopodal, visceral, and subrenal sinuses, from which it is pumped to the pulmonary wall and reoxygenated, crossing the renal and pulmonary veins and finally reaching the heart (Paraense 1973).

Larvae penetrating the host's tegument either remain in fibromuscular tissue or invade hemolymphatic sinuses, which are abundant in this tissue, acquiring a spongy aspect. Ingested larvae could also reach the hemocoel, after the digestive tract transposition, from where they can access the circulatory system and other organs (Figs. 2, 15, 16 and 3 , 17). The presence of a large amount of larvae in the kidneys and in the mantle cavity expresses the importance of such structures in the circulatory system.

Intense hemolymphatic vascularization favors the presence of a large number of larvae in fibromuscular tissue (Fig. 2, 11, 12, and 13). Larvae distribution throughout several organs and sites (Table 1) is also related to vascular or ductal systems. For instance, larvae initially located in the digestive tract lumen may migrate to the digestive gland through its duct (Fig. 1, 6 and 7), which communicates with the posterior portion of the stomach (Paraense 1972). In this case, the parasite could either remain in the digestive gland or invade the hemocoel.

In S. marginata (Mendonça et al. 1999, 2003), larvae clearly predominated in fibromuscular tissue, the circulatory system, and kidneys, with occasional invasions of other organs, as was also verified here with Omalonyx sp. Thus, in both species, the migration route is related to the 
Fig. 4 Scheme of $A$.

costaricensis larval migration route in Omalonyx sp. (arrow). Probable pathways were also indicated (arrow with broken lines and question mark)

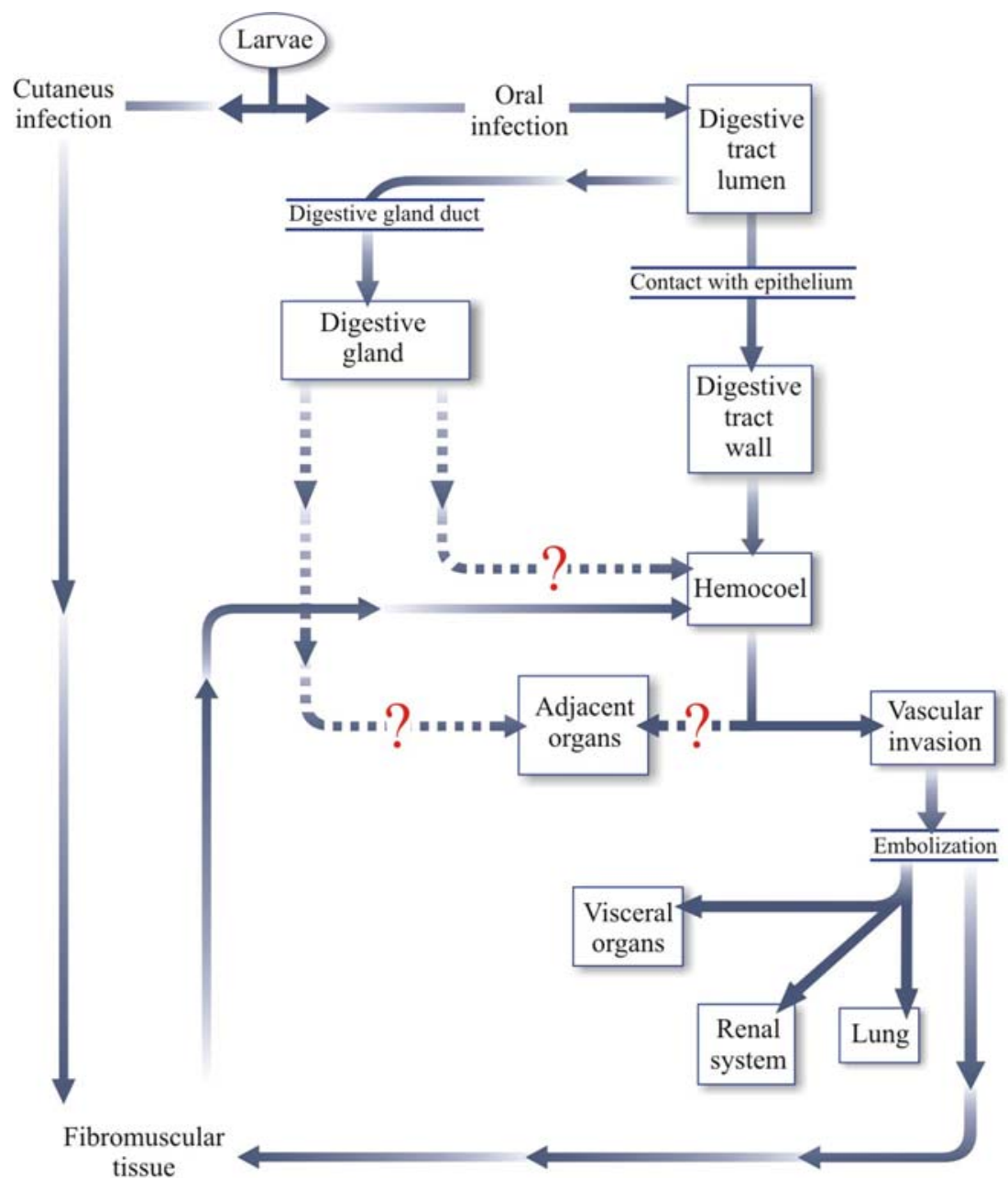

circulatory system pathways. A general scheme of larvae migration pathways is depicted in Fig. 4.

Studies using different populations/strains of Biomphalaria and Schistosoma mansoni reported the variability in host responses, according to their geographical origin and species (Newton 1952; Guaraldo et al. 1981; Godoy et al. 1997; Borges et al. 1998).

Both mollusk species, Omalonyx sp. and S. marginata, exhibit perilarval hemocyte reaction; however, in Omalonyx sp., the reaction varied, being stronger around L2 (8 to 13 days after infection; Fig. 3, 19 and 20) than in L3 (Fig. 2, 14). In $S$. marginata, even on the 30 th day of infection, the perilarval reaction remains strong. The low or null reaction to L3 in Omalonyx sp. probably favors L3 spontaneous displacement through the tissues and its direct elimination to the exterior, without the granulomatous hemocyte reaction interference as described in Veronicellidae (Conejo and Morera 1988; Mendonça et al. 2003). The local preference of hemocytes to the concave side of L2 is probably due to more accumulation of larval products in this area.

Literature devoted to parasite/mollusk interactions is mostly related to trematodes, lacking information on nematodes. Studies comparing the morphological aspects of the hemocyte reaction to $A$. costaricensis infection in different species of mollusks could contribute to better understanding of the innate immune system in invertebrates.

Acknowledgments We thank Iolanda de Olinda Pedro, Andréa Natividade da Silva, Alexandra M dos Anjos, Luciana S Souza, Luzia HP Barroso (Departamento de Patologia, Instituto Oswaldo Cruz, Rio de Janeiro, RJ), Sueleny Silva Ferreira Teixeira, Marcílio da Silva Tomaz, Vera Lúcia de Jesus Mariano, and Wanderley Alves da Silva (CPqRR, Fiocruz, Belo Horizonte, MG), for their technical assistance, and Daniel Coscarelli (Laboratório de Malacologia, Universidade Federal de Minas Gerais, Belo Horizonte, MG) for drawing Fig. 4. Photography was by Lângia C. Montresor. This experiment complies with the current laws of Brazil. 


\section{References}

Banevicius NMS, Zanotti-Magalhães EM, Magalhães LA, Linhares X (2006) Behavior of Angiostrongylus costaricensis in Planorbids. Braz J Biol 66:199-204

Barker GM (2001) The biology of terrestrial molluscs. CABI, New York

Bonetti VCBDO, Graeff-Teixeira C (1998) Angiostrongylus costaricensis and the intermediate hosts: observations on elimination of $\mathrm{L}_{3}$ in the mucus and inoculation of $\mathrm{L}_{1}$ through the tegument of molluscs. Rev Soc Bras Med Trop 31:289-294

Borges CM, Souza CP, Andrade AA (1998) Histopathologic features associated with susceptibility and resistance of Biomphalaria snails to infection with Schistosoma mansoni. Mem Inst Oswaldo Cruz 93(Suppl I):117-121

Carson FL, Martin JH, Lynn JA (1973) Formalin fixation for electron microscopy: a re-evaluation. Am J Clin Pathol 59:365-375

Casey SP, Bakke TA, Harris PD, Cable J (2003) Use of ITS rDNA for discrimination of European green- and brown-banded sporocysts within the genus Leucochloridium Carus, 1835 (Digenea: Leucochloriidae). Syst Parasitol 56:163-168

Cheng TC, Alicata JE (1965) On the modes of infection of Achatina fulica by the larvae of Angiostrongylus cantonensis. Malacol 2:267-274

Chiaradia LA, Milanez JM, Graeff-Teixeira C, Thomé JW (2004) Lesmas: pragas da agricultura e ameaça à saúde humana. Agropecu Catarin 17:70-74

Conejo ME, Morera P (1988) Influencia de la edad de los veronicelideos en la infección con Angiostrongylus costaricensis. Rev Biol Trop 36:519-526

Duarte Z, Morera P, Davila P, Gantier JC (1992) Angiostrongylus costaricensis natural infection in Vaginulus plebeius in Nicaragua. Ann Parasitol Hum Comp 67:94-96

Godoy A, Souza CP, Guimarães CT, Andrade ZA (1997) Unusual histological findings in Biomphalaria glabrata with high degree of resistance to Schistosoma mansoni miracidia. Mem Inst Oswaldo Cruz 92:121-122

Graeff-Teixeira C, Thomé JW, Pinto SCC, Camillo-Coura L, Lenzi HL (1989) Phyllocaulis variegatus - an intermediate host of Angiostrongylus costaricensis in South Brazil. Mem Inst Oswaldo Cruz 84:65-68

Graeff-Teixeira C, Thiengo SC, Thomé JW, Medeiros AB, CamilloCoura L, Agostini AA (1993) On the diversity of molluscs intermediate hosts of Angiostrongylus costaricensis Morera \& Céspedes, 1971 in southern Brazil. Mem Inst Oswaldo Cruz 88:487-489

Guaraldo AMA, Magalhães LA, Rangel HA, Pareja G (1981) Evolução dos esporocistos de Schistosoma mansoni Sambon, 1907 em Biomphalaria glabrata (Say, 1818) e Biomphalria tenagophila (D’Orbigny, 1835). Rev Saúde Publica 15:436-438

Hobmaier A, Hobmaier M (1934) The route of infestation and the site of localization of lung worms in mollusks. Science 80:229

Kaminsky RG, Andrrews K, Mor NR (1987) Angiostrongylus costaricensis en babosas en Honduras: estudio preliminar. Rev Méd Hondur $55: 4-8$

Laitano AC, Genro JP, Fontoura R, Branco SSL, Maurer RL, GraeftTeixeira C, Milanez JM, Chiaradia LA, Thomé JW (2001) Report on the occurrence of Angiostrongylus costaricensis in southern Brazil, in a new intermediate host from the genus Sarasinula (Veronicellidae, Gastropoda). Rev Soc Bras Med Trop 34:95-97

Lee DL (1965) The physiology of nematodes. University reviews in biology. Oliver \& Boyd, London

Lima LC, Massara CL, Souza CP, Vidigal TD, Lenzi HL, Carvalho OS (1992) Suscetibilidade de planorbídeos da região metropolitana de
Belo Horizonte, MG (Brasil) ao Angiostrongylus costaricensis (Nematoda: Angiostrongylidae). Rev Inst Med Trop São Paulo 34:399-402

Lutz A (1921) Observações sobre o gênero Urogonimus e uma nova forma de Leucochloridium em novo hospedador. Mem Inst Oswaldo Cruz 13:136-140

Mendonça CLGF, Carvalho OS, Mota EM, Pelajo-Machado M, Caputo LFG, Lenzi HL (1999) Penetration sites and migratory routes of Angiostrongylus costaricensis in the experimental intermediate host (Sarasinula marginata). Mem Inst Oswaldo Cruz 94:549-556

Mendonça CLGF, Carvalho OS, Mota EM, Machado PM, Caputo LFG, Lenzi HL (2003) Angiostrongylus costaricensis and Experimental infection of Sarasinula marginata - II. Elimination routes. Mem Inst Oswaldo Cruz 98:893-898

Morera P (1973) Life history and redescription of Angiostrongylus costaricensis (Morera and Céspedes, 1971). Am J Trop Med Hyg 22:613-621

Morera P, Ash LR (1971) Investigacion del huesped intermediario de Angiostrongylus costaricensis (Morera y Céspedes, 1971). Bol Chil Parasitol 25:135

Morera P, Céspedes R (1971) Angiostrongylus costaricensis n.sp (Nematoda: Metastrongyloidea), a new lungworm occurring in man in Costa Rica. Rev Biol Trop 18:173-185

Morera P, Lazo R, Urquizo J, Laguno M (1983) First record of Angiostrongylus costaricensis (Morera and Céspedes, 1971) in Ecuador. Am J Trop Med Hyg 32:1460-1461

Mota EM, Lenzi HL (2005) Angiostrongylus costaricensis: complete redescription of the migratory pathways based on experimental Sigmodon hispidus infection. Mem Inst Oswaldo Cruz 100: $407-420$

Newton WL (1952) The comparative tissue reaction of two strains of Austrolorbis glabratus to infection with Schistosoma mansoni. J Parasitol 362:366

Paraense WL (1972) Fauna planorbídica do Brasil. In: Lacaz CS, Baruzzi GR, Siqueira WJR (eds) Introdução à geografia médica do Brasil. Edgard Blucher and USP, São Paulo

Paraense WL (1973) The molluscan intermediate host of Schistosoma mansoni in Brazil. In: Ansari N (ed) Epidemiology and control of schistosomiasis. S. Karger, Basel

Patterson CM (1971) Taxonomic studies of the land snail family Succineidae. Malacol Rev 4:131-202

Rambo RP, Agostini AA, Graeff-Teixeira C (1997) Abdominal angiostrongylosis in Southern Brazil-prevalence and parasitic burden in mollusc intermediate host from eighteen endemic foci. Mem Inst Oswaldo Cruz 92:9-14

Richards CS, Merritt JW (1967) Studies on Angiostrongylus cantonensis in molluscan intermediate hosts. J Parasitol 53:382-388

South A (1992) Terrestrial slugs: biology, ecology and control. Chapman \& Hall, London

Thiengo SC (1996) Mode of Infection Sarasinula marginata (Mollusca) with larvae of Angiostrongylus costaricensis (Nematoda). Mem Inst Oswaldo Cruz 97:277-278

Tillier S (1981) South American and Juan Fernandez Succineid slugs (Pulmonata). J Molluscan Stud 47:125-146

Ubelaker JE, Bullick GR, Caruso J (1980) Emergence of third-stage larvae of Angiostrongylus costaricensis Morera and Cespedes 1971 from Biomphalaria glabrata (Say). J Parasitol 66:856-857

Wallace GD, Rosen L (1969) Technique for recovering and identifying larvae of Angiostrongylus cantonensis from molluscs. Malacol 7:427-438

Willcox HP, Coura JR (1989) Nova concepção para o método de Baermann-Moraes-Coutinho na pesquisa de larvas de nematódeos. Mem Inst Oswaldo Cruz 84:539-565 